\title{
Improvement of surgical tactics in acute destructive cholecystitis
}

The aim of the work: to improve the quality of treatment of patients with acute destructive cholecystitis by improving surgical tactics. Materials and Methods. The work is based on the evaluation of the results of surgical treatment of patients with acute destructive cholecystitis who were treated in the surgical departments of the Clinic No. 1 of Samarkand State Medical Institute (clinical base of the departments of Surgical Diseases No. 1 and General Surgery of the Samarkand State Medical Institute) for the period from 2016 to 2020. Depending on the treatment tactics, the patients were divided into groups. In the period from 2016 to 2017,82 (40.8 \% of 201 ) patients with acute destructive forms of cholecystitis underwent cholecystectomy by laparoscopic method and traditional wide access. They made up a comparison group. From 2018 to 2020, 119 (59.2 \% of 201) patients with acute destructive cholecystitis underwent cholecystectomy by laparoscopic method and from minilaparotomic access. They made up the main group.

Results and Discussion. When studying the frequency of local complications in our work, we took into account only those complications that were accompanied by a significant deterioration in the patient's condition, posed a threat to his life and required active conservative or surgical treatment.

Local postoperative complications included damage to the biliary tract, bile leakage through the drainage of the abdominal cavity, massive bleeding from the abdominal cavity, infectious intra-abdominal complications.

The frequency of hepaticocholedocha damage in acute cholecystitis complicated by dense infiltration during standard LCE was observed by us in 1 out of 23 patients ( $4.3 \%)$ of the comparison group.

Key words: cholelithiasis; cholecystitis; cholecystectomy; laparoscopy; minilaparotomy; laparotomy; conversion; complication.

The relevance of the study. According to the World Health Organization, in the world, due to the increase in the incidence of cholelithiasis, there is an increase in the number of patients with destructive forms of this pathology $[1,3,10]$. Despite the great success of minimally invasive surgery in the treatment of cholelithiasis, many authors include some destructive forms of acute cholecystitis (phlegmonous and gangrenous cholecystitis with amniotic infiltration in the neck of the gallbladder with a disease duration of more than 72 hours) in the group of contraindications to performing cholecystectomy from a minilaparotomy approach $[3,7]$. This is due to the technical complexity of performing cholecystectomy from minilaparotomy access in destructive forms of acute cholecystitis complicated by dense amniotic infiltrate, which often leads to the transition to a wide laparotomy with the development of related complications in the postoperative period [5, 9, 11, 12]. It is in patients with acute destructive cholecystitis when performing minimally invasive cholecystectomy that iatrogenic damage to the extrahepatic bile ducts, hepatoduodenal ligament vessels or liver gates is most common. At the same time, the transition to a wide laparotomy is not the optimal way to solve the problem of surgical treatment of acute destructive cholecystitis [2, 4, 8, 13].

Taking into account the fact that acute destructive cholecystitis is a common complication of the gastrointestinal tract, the development of atypical methods of performing minimally invasive interventions that allow avoiding transitions to a wide laparotomy is of great practical interest $[6,11]$. It seems to us relevant and practically significant to determine the indications for each of the atypical methods of cholecystectomy within the framework of mini-laparotomy access with the development of issues of optimal technical support and the most rational surgical techniques when performing surgical intervention, as well as the study of the immediate and long-term results of their implementation.

The aim of the work is to improve the quality of treatment of patients with acute destructive cholecystitis by improving surgical tactics.

Materials and Methods. The work is based on the evaluation of the results of surgical treatment of patients with acute destructive cholecystitis who were treated in the surgical departments of the Clinic No. 1 of Samarkand State Medical Institute (clinical base of the departments of Surgical Diseases No.1 and General Surgery of the Samarkand State Medical Institute) for the period from 2016 to 2020. Depending on the treatment tactics, the patients were divided into groups. In the period from 2016 to 2017, 82 (40.8 \% of 201) patients with acute destructive forms of cholecystitis underwent cholecystectomy by laparoscopic method and traditional wide access. They made up a comparison group. From 2018 to 2020, 119 (59.2 \% of 201) patients with acute destructive cholecystitis underwent cholecystectomy by laparoscopic method and from minilaparotomic access. They made up the main group. 
The study included all operated patients admitted to the hospital with clinical symptoms of acute destructive cholecystitis.

We excluded patients with the phenomena of mechanical jaundice or cholangitis from our study, since these complications are accompanied by a higher level of mortality and complications and may distort the data of our study. dard.

Instrumental preoperative examination was stan-

In the comparison group, initially 43 (52.4\% of 82) patients were scheduled for cholecystectomy by laparoscopic method. Of these, only 23 patients completed cholecystectomy by laparoscopic method, and $20 \mathrm{pa}-$ tients underwent conversion, i.e. cholecystectomy was completed by traditional wide access. 39 (47.6 \% of 82) patients from the comparison group had cholecystectomy planned with a wide traditional access.

The tactics of treatment of patients in the main group differed from the comparison group in that the choice of optimal surgical access during cholecystectomy was more differentiated, and the access itself was less traumatic.

Until 2018, when performing cholecystectomy for acute destructive cholecystitis, they mainly used exclusively traditional wide incisions of the anterior abdominal wall, which greatly facilitate the surgeon to perform the main stage of the operation, but still have a number of serious and well-known disadvantages - high traumatic intervention, increased risk of postoperative wound complications, unsatisfactory cosmetic results, a long period of early rehabilitation, etc. These circumstances prompted us to search for more gentle, less traumatic and at the same time convenient for the operator surgical accesses to the gallbladder and revision of the bile ducts.

As a result, since 2018, in acute destructive cholecystitis, we have begun to use widely the so-called "mini-access", taking into account the individual characteristics for each patient.

When choosing cholecystectomy by laparoscopic method or from minilaparotomic access, we were guided by the results of preoperative diagnosis. Clinical signs of the course of acute cholecystitis were combined with ultrasound data.

In the main group of patients, cholecystectomy was initially planned for 47 (39.5\% of 119) patients by laparoscopic method, but due to the complexity of continuing the operation and according to diagnostic laparoscopy, 9 (19.1\%) patients out of 47 patients underwent conversion. The reason for the conversion is shown in Table 1.

Table 1. The reason for the conversion of laparoscopic cholecystectomy in the main group

\begin{tabular}{||l|c|c||}
\hline \multicolumn{1}{|c|}{ The reason for the conversion } & \multicolumn{2}{|c||}{ Amount of patients (n=9) } \\
\cline { 2 - 3 } & absolute & 77.8 \\
\hline The duration of the operation is more than 30 minutes & 3 & 44.4 \\
\hline The cystic and common bile duct are not identified & 3 & 22.2 \\
\hline $\begin{array}{l}\text { A wide cystic duct with a thickened wall is identified, there is a danger of slipping } \\
\text { off the clips }\end{array}$ & 2 & 11.1 \\
\hline Bleeding & 1 & 2 \\
\hline
\end{tabular}

As can be seen from Table 1, the reason for the conversion in 3 patients was the duration of identification of the cystic duct and the main bile ducts was more than 30 minutes, in 3 more patients, due to dense infiltration in the subhepatic region, it took more than 30 minutes to identify the wall of the gallbladder. In 2 cases, according to diagnostic laparoscopy, there was a danger of clips slipping due to a wide cystic duct with a thickened wall. In 1 case, the conversion was caused by bleeding from the cystic artery with a favorable outcome.

72 (60.5\% of 119) patients, taking into account the clinical signs of the course of acute cholecysti- tis, the existing concomitant somatic pathology and the data of the ultrasound study, cholecystectomy was performed through a minilaparotomic access.

Thus, in the main group of patients, 38 (31.9\% of 119) patients underwent cholecystectomy by laparoscopic method and 81 (68.1\% of 119) patients with acute destructive cholecystitis underwent cholecystectomy through a minilaparotomy approach.

Based on the clinical course and instrumental studies of acute destructive cholecystitis, we have developed and implemented in clinical practice an optimal therapeutic and tactical algorithm for managing patients with acute destructive cholecystitis (Fig. 1). 


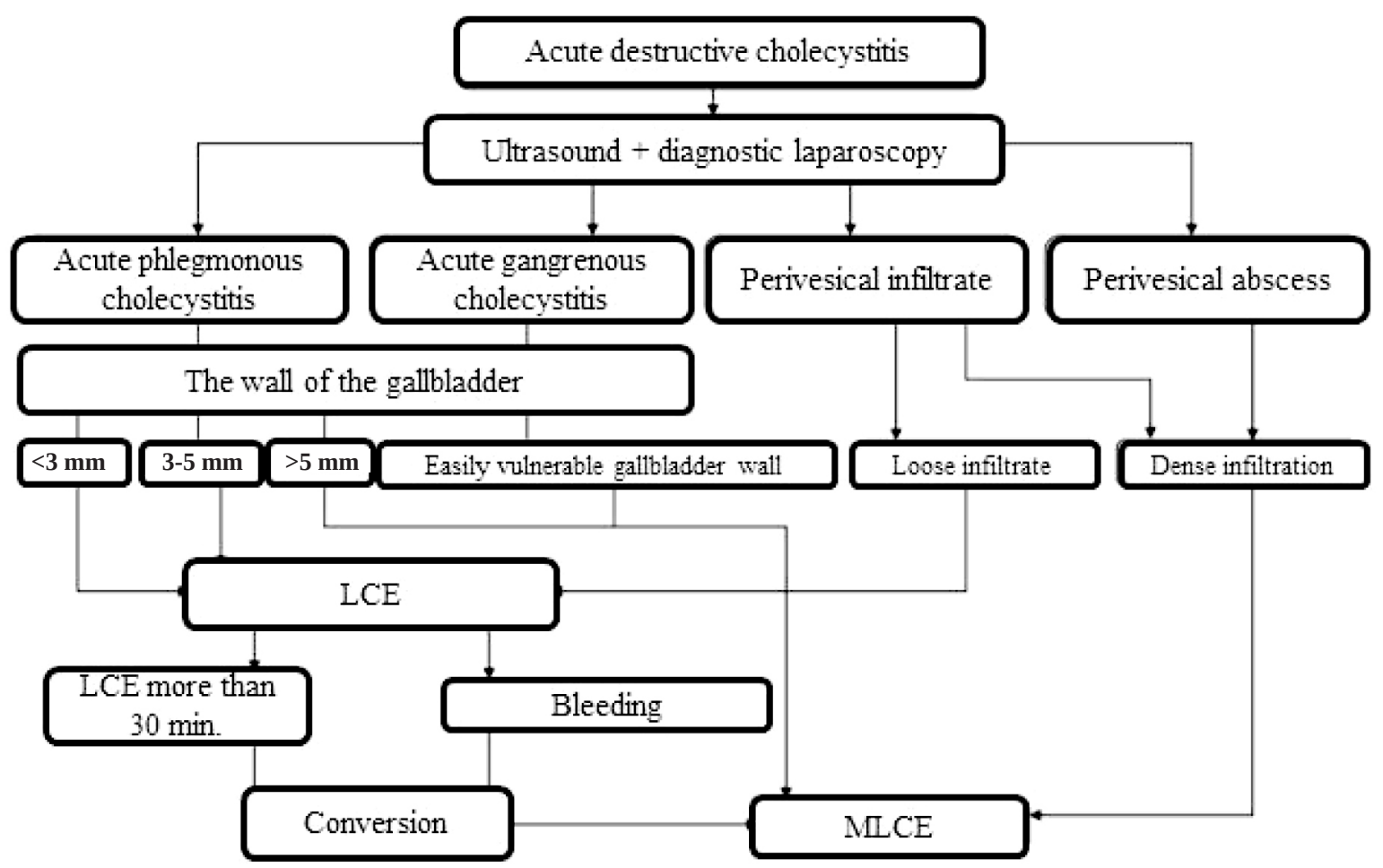

Fig. 1. Therapeutic and tactical algorithm for the management of patients with acute destructive cholecystitis.

Results and Discussion. When studying the frequency of local complications in our work, we took into account only those complications that were accompanied by a significant deterioration in the patient's condition, posed a threat to his life and required active conservative or surgical treatment.

Local postoperative complications included damage to the biliary tract, bile leakage through the drainage of the abdominal cavity, massive bleeding from the abdominal cavity, infectious intra-abdominal complications.

The frequency of hepaticocholedocha damage in acute cholecystitis complicated by dense infiltration during standard LCE was observed by us in 1 out of 23 patients (4.3\%) of the comparison group. The comparative characteristics of other local complications after CE by various methods in the studied groups are presented in Table 2 .

Table 2. The frequency of postoperative complications in patients after cholecystectomy

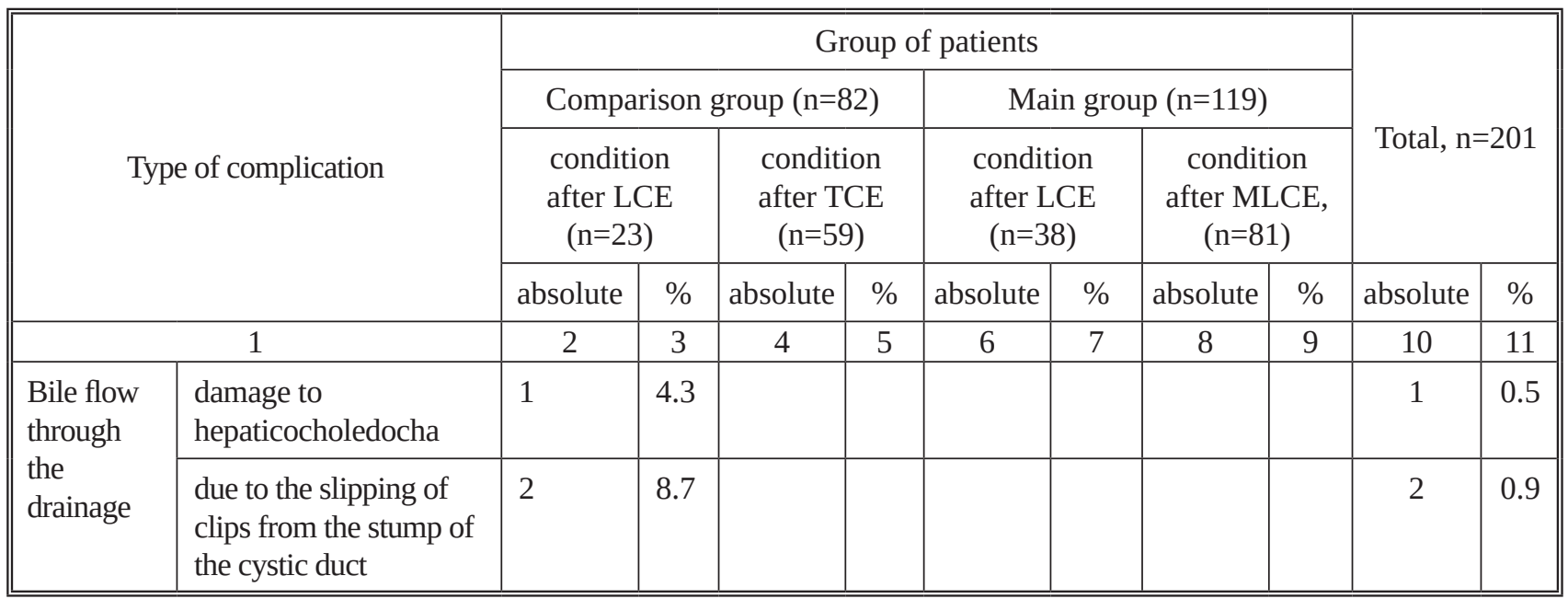


Continuation of Table 2

\begin{tabular}{|l|l|c|c|c|c|c|c|c|c|c|c||}
\hline \multicolumn{1}{|c|}{1} & 2 & 3 & 4 & 5 & 6 & 7 & 8 & 9 & 10 & 11 \\
\hline $\begin{array}{l}\text { due to the failure of the } \\
\text { stump of the cystic duct }\end{array}$ & & & 1 & 1.7 & & & & 1 & 0.5 \\
\hline from Lyushko's moves & & & 2 & 3.4 & & & 1 & $1.2 *$ & 3 & 1.5 \\
\hline Biloma in the subhepatic region & 1 & 4.3 & & & 1 & 2.6 & & & 2 & 0.9 \\
\hline Biliary peritonitis & & & 1 & 1.7 & & & & & 1 & 0.5 \\
\hline Bleeding & 1 & 4.3 & & & & & & & 1 & 0.5 \\
\hline Suppuration of a postoperative wound & & & 2 & 3.4 & & & & & 2 & 0.9 \\
\hline Total complications & 5 & 21.7 & 6 & 10.2 & 1 & $2.6 * *$ & 1 & 1.2 & 13 & 6.5 \\
\hline Number of patients with complications & 4 & 17.4 & 5 & 8.5 & 1 & 2.6 & 1 & 1.2 & 11 & 5.5 \\
\hline Criteria $x^{2}$ & & & Df=1; $x^{2}=4.954 ; \mathrm{p}=0.027$ & \\
\hline
\end{tabular}

Note: * - differences relative to the control group data are significant $(*-\mathrm{P}<0.05$, ** $-\mathrm{P}<0.001)$

As follows from the data in Table 2, the frequency of local complications after performing CE in the comparison group was observed in 11 (13.4 \%) of 82 patients. This indicator was significantly higher than in patients of the main group, i.e. in 2 (1.7 \%) of 119 patients. In the main group of patients after LCE, after standard and non-standard MLCE, such terrible complications as damage to the hepaticocholedoch were not observed.

The analysis of methods of treatment of local complications in patients with acute destructive cholecystitis, after CE in various ways in the studied groups, is presented in Table 3.

Table 3. Methods of treatment of local complications after cholecystectomy in the study groups

\begin{tabular}{|c|c|c|c|c|c|c|}
\hline \multirow[b]{2}{*}{$\begin{array}{l}\text { Research } \\
\text { groups }\end{array}$} & \multirow{2}{*}{\multicolumn{2}{|c|}{ Type of complication }} & \multicolumn{4}{|c|}{ Treatment method } \\
\hline & & & Conservative & $\begin{array}{l}\text { Conversion, } \\
\text { external } \\
\text { drainage of the } \\
\text { GC stump }\end{array}$ & $\begin{array}{l}\text { Laparo- } \\
\text { tomy }\end{array}$ & $\begin{array}{l}\text { Puncture } \\
\text { drainage under } \\
\text { ultrasound } \\
\text { control }\end{array}$ \\
\hline 1 & & 2 & 3 & 4 & 5 & 6 \\
\hline \multirow{8}{*}{$\begin{array}{l}\text { Comparison } \\
\text { group } \\
(\mathrm{n}=82)\end{array}$} & \multirow{4}{*}{$\begin{array}{l}\text { Bile } \\
\text { discharge }\end{array}$} & $\begin{array}{l}\text { damage to hepaticocholedocha after } \\
\text { LCE }(n=1)\end{array}$ & & 1 & & \\
\hline & & $\begin{array}{l}\text { due to the slipping of clips from the } \\
\text { stump of the cystic duct after LCE } \\
(n=2)\end{array}$ & 1 & & 1 & \\
\hline & & $\begin{array}{l}\text { due to the failure of the stump of the } \\
\text { cystic duct after TCE }(n=1)\end{array}$ & 1 & & & \\
\hline & & $\begin{array}{l}\text { from Lyushko's moves after TCE } \\
(\mathrm{n}=2)\end{array}$ & 1 & & 1 & \\
\hline & \multicolumn{2}{|c|}{ Biloma in the subhepatic region after LCE $(n=1)$} & & & & 1 \\
\hline & \multicolumn{2}{|c|}{ Biliary peritonitis after TCE $(n=1)$} & & & 1 & \\
\hline & \multicolumn{2}{|c|}{ Bleeding after LCE (n=1) } & & & 1 & \\
\hline & \multicolumn{2}{|c|}{$\begin{array}{l}\text { Suppuration of the postoperative wound after } \\
\text { TCE }(n=2)\end{array}$} & 2 & & & \\
\hline
\end{tabular}


Continuation of Table 3

\begin{tabular}{||l|l|c|c|c|c||}
\hline \multicolumn{1}{|c|}{1} & \multicolumn{1}{|c|}{2} & 3 & 4 & 5 & 6 \\
\hline $\begin{array}{l}\text { Main } \\
\text { group } \\
(\mathrm{n}=119)\end{array}$ & $\begin{array}{l}\text { Bile discharge from Lyushko's moves after } \\
\text { MLCE (n=1) }\end{array}$ & 1 & & & \\
\cline { 2 - 6 } & Biloma in the subhepatic region after LCE (n=1) & & & & 1 \\
\hline Total & 6 & 1 & 4 & 2 \\
\hline
\end{tabular}

Conclusions. 1. The proposed therapeutic and diagnostic algorithm for the management of patients with acute destructive cholecystitis allowed laparoscopic cholecystectomy and cholecystectomy from a mini-access, respectively, in $31.9 \%$ and $68.1 \%$ of cases in the main group.

\section{LITERATURE}

1. Laparoscopic cholecystectomy in the treatment of acute cholecystitis: comparison of results between early and late cholecystectomy / N. Acar, K. Atahan, H. Bağ [et al.] // Pan. Afr. Med. J. 2017. - Vol. 31. - P. 26-49. DOI: 10.11604/pamj.2017.26.49.8359. 2. Alexandrovich V. E. Gas-free laparoscopy in the treatment of patients with acute destructive cholecystitis and increased anesthesiological and operational risk / V. E. Alexandrovich, A. Yu. Nekrasov, A. V. Sergeev // Clinical Gerontology. - 2015. Vol. 21. - P. 11-12.

3. Population analysis of $\mathbf{4 1 1 3}$ patients with acute cholecystitis: determining the optimal time for laparoscopic cholecystectomy / W. Banz, T. Gsconer, D. Kandinas, J. Guller // Ann. Surg. - 2011. - Vol. 254. - P. 964-970. DOI: 10.1097/SLA.0b013e318228d31c. 4. Minimally invasive methods of treatment of patients with acute cholecystitis / Z. Ya. Saydullaev, S. S. Davlatov, Z. I. Murtazaev, K. E. Rakhmanov // Annals of the Romanian Society for Cell Biology. - 2021. - Vol. 25 (4). - P. 1956-1961.

5. Early versus delayed-interval laparoscopic cholecystectomy for acute cholecystitis: a metaanalysis / H. Lau, C. Y. Lo, N. G. Patil, W. K. Yuen // Surg Endosc. - 2006. - Vol. 20 (1). - P. 82-87.

6. Малиновский А. В. Перший досвід міні-лапароскопічної холецистектомії при гострому холециститі / А. В. Малиновский, М. М. Галимон, С. Ю. Бадион // Шпитальна хірургія. Журнал імені Л. Я. Ковальчука. - 2018. - № 4. - С. 85-89. 7. Operative timing of laparoscopic cholecystectomy for acute cholecystitis in a japanese institute / O. Masayuki, I. Yukio, Y. Kazuhiro [et al.] // Journal of the Society Laparoendoscopic Surgery. - 2012. - Vol. 16 (1). - P. 65-70.

\section{REFERENCES}

1. Acar, T., Kamer, E., Acar, N., Atahan, K., Bağ, H., Haciyanlı, M., \& Akgül, Ö. (2017). Laparoscopic cholecystectomy in the treatment of acute cholecystitis: comparison of results between early and late cholecystectomy. The Pan African Medical Journal, 26. 2. Alexandrovich, V.E., Nekrasov, A.Yu., \& Sergeev, A.V. (2015). Gas-free laparoscopy in the treatment of patients with acute destructive cholecystitis and increased anesthesiological
2. The tactics of surgical treatment of patients with destructive cholecystitis, taking into account an integrated approach to the choice of access, allowed to improve the quality of care by reducing the frequency of immediate postoperative complications from $13.4 \%$ (11 patients in the comparison group) to $1.7 \%$ (2 patients in the main group).

8. Саволюк С. І. Діагностичний алгоритм у хворих із гострим калькульозним холециститом та підозрою на холедохолітіаз / С. І. Саволюк, Б. В. Свиридюк // Шпитальна хірургія. Журнал імені Л. Я. Ковальчука. - 2016. - № 4. - С. 33-36. 9. Terho P. M. Laparoscopic cholecystectomy for acute calculous cholecystitis: a retrospective study assessing risk factors for conversion and complications / P. M. Terho, A. K. Leppäniemi, P. J. Mentula // World J. Emerg. Surg. - 2016. - Vol. 16. - P. 11-54.

10. Tokyo Committee for the Review of Recommendations of TG13: Surgical Treatment of Acute Cholecystitis / J. Yamashita, T. Takada, S. M. Strasberg [et al.] // J. Hepatobilary Pancreat. Sci. - 2013. - Vol. 20. - P. 89-96. DOI: 10.1007/s00534-012-0567-x. 11. Simultaneous surgical treatment tactics of acute destructive cholecystitis combined with choledocholithiasis: A case report / D. T. Zhumatayev, A. N. Baimakhanov, M. K. Abdykadyrov [et al.] // Int. J. Surg. Case Rep. - 2020. - Vol. 70. - P. 230-233. DOI: 10.1016/j.ijscr.2020.04.081.

12. Терлецький О. М. Проблема діагностики малосимптомного холедохолітіазу в пацієнтів із гострим калькульозним холециститом / О. М. Терлецький, В. І. Коломійцев // Шпитальна хірургія. Журнал імені Л. Я. Ковльчука. - 2018. - № 2. - С. 73-77.

13. Фіра Д. Б. Інтраопераційний алгоритм дій при виконанні лапароскопічної холецистектомії у хворих із супутньою варикозною хворобою вен нижніх кінцівок / Д. Б. Фіра // Шпитальна хірургія. Журнал імені Л. Я. Ковльчука. - 2016. - № 2. - C. 99-102. 
of patients with acute cholecystitis. Annals of the Romanian Society for Cell Biology, 1956-1961.

5. Lau, H., Lo, C.Y., Patil, N.G., \& Yuen, W.K. (2006). Early versus delayed-interval laparoscopic cholecystectomy for acute cholecystitis. Surgical Endoscopy and Other Interventional Techniques, 20 (1), 82-87.

6. Malinovsky, A.V., Galimon, M.M., \& Badion, S.Y. (2018). Pershyi dosvid mini-laparoskopichnoi kholetsystektomii pry hostromu kholetsystyti [First experience of mini-laparoscopic cholecystectomy]. Shpytalna khirurhiia. Zhurnal imeni L.Ya. Kovlchuka - Hospital Surgery. Journal named after L.Ya. Kovalchuk, 4, 85-89 [in Ukrainian].

7. Ohta, M., Iwashita, Y., Yada, K., Ogawa, T., Kai, S., Ishio, T., ... \& Kitano, S. (2012). Operative timing of laparoscopic cholecystectomy for acute cholecystitis in a Japanese institute. JSLS: Journal of the Society of Laparoendoscopic Surgeons, 16 (1), 65. 8. Savoliuk, S.I., \& Svyrydiuk, B.V. (2016). Diahnostychnyi alhorytm u khvorykh iz hostrym kalkuloznym kholetsystytom ta pidozroiu na kholedokholitiaz [Diagnostic algorithm for patients with an acute calculary cholecystitis and suspicion on choledocholithiasis]. Shpytalna khirurhiia. Zhurnal imeni L.Ya. Kovlchuka - Hospital Surgery. Journal named after L.Ya. Kovalchuk, 4, 33-36 [in Ukrainian].

9. Terho, P.M., Leppäniemi, A.K., \& Mentula, P.J. (2016). Laparoscopic cholecystectomy for acute calculous cholecystitis: a retrospective study assessing risk factors for conversion and compli- cations. World Journal of Emergency Surgery, 11 (1), 1-9. 10. Yamashita, Y., Takada, T., Strasberg, S.M., Pitt, H.A., Gouma, D.J., Garden, O.J., ..., \& Supe, A.N. (2013). TG13 surgical management of acute cholecystitis. J. Hepatobiliary Pancreat. Sci., 20, 89-96. DOI: 10.1007/s00534-012-0567-x.

11. Zhumatayev, D.T., Baimakhanov, A.N., Abdykadyrov, M.K., Nurmakov, D.A., Raimkhanov, A.D., Smagulov, A.M., \& Abdiyev, N.M. (2020). Simultaneous surgical treatment tactics of acute destructive cholecystitis combined with choledocholithiasis: A case report. International Journal of Surgery Case Reports, 70, 230-233.

12. Terletskyy, O.M., \& Kolomiytsev, V.I. (2018). Problema diahnostyky malosymptomnoho kholedokholitiazu v patsiientiv iz hostrym kalkuloznym kholetsystytom [The problem of diagnostics of small symptomatic choledocholithiasis in patients with acute calculus cholecystitis]. Shpytalna khirurhiia. Zhurnal imeni L.Ya. Kovlchuka - Hospital Surgery. Journal named after L.Ya. Kovalchuk, 2, 73-77 [in Ukrainian].

13. Fira, D.B. (2016). Intraoperatsiinyi alhorytm dii pry vykonanni laparoskopichnoi kholetsystektomii u khvorykh iz suputnioiu varykoznoiu khvoroboiu ven nyzhnikh kintsivok [Intraoperative sequence of actions when performing laparoscopic cholecystectomy in patients with concomitant varicose veins of the lower extremities]. Shpytalna khirurhiia. Zhurnal imeni L.Ya. Kovlchuka - Hospital Surgery. Journal named after L.Ya. Kovalchuk, 2, 99-102 [in Ukrainian].

Отримано 20.07.2021

Електронна адреса для листування: salimdavlatov@sammi.uz

\title{
3. Я. САЙДУЛЛЛАЕВ
}

Самаркандський державний медичний інститут ${ }^{1}$, Самарканд, Республіка Узбекистан Бухарський державний медичний інститут², Бухара, Республіка Узбекистан

\section{ВДОСКОНАЛЕННЯ ХІРУРГІЧНОЇ ТАКТИКИ ПРИ ГОСТРОМУ ДЕСТРУКТИВНОМУ ХОЛЕЦИСТИТІ}

\begin{abstract}
Мета роботи: покращити якість лікування хворих на гострий деструктивний холецистит шляхом удосконалення хірургічної тактики.

Матеріали і методи. У роботі викладено оцінку результатів хірургічного лікування хворих із гострим деструктивним холециститом, які пройшли лікування в хірургічних відділеннях 1-клініки Самаркандського державного медичного інституту (клінічна база кафедр хірургічних хвороб № 1 та загальної хірургії Самаркандського державного медичного інституту) за період з 2016 до 2020 р. Залежно від тактики лікування хворих розділили на групи. У період із 2016 до 2017 р. 82 (40,8 \% з 201) хворим із гострими деструктивними формами холециститу холецистектомію виконано лапароскопічним методом і традиційним широким доступом. Ці хворі склали групу порівняння. 32018 до 2020 р. 119 (59,2 \% з 201) хворим із гострим деструктивним холециститом холецистектомію виконано лапароскопічним методом і з мінілапаротомного доступу. Ці хворі склали основну групу.

Результати досліджень та їх обговорення. При вивченні частоти місцевих ускладнень у роботі ми враховували тільки ті ускладнення, які супроводжувалися значним погіршенням стану пацієнта, становили загрозу його життю і потребували проведення активного консервативного або операційного лікування.

До місцевих післяопераційних ускладнень ми відносили пошкодження жовчних шляхів, жовчотеча по дренажу черевної порожнини, масивна кровотеча з черевної порожнини, інфекційні внутрішньочеревні ускладнення.

Частота ушкоджень гепатикохоледоха при гострому холециститі, ускладненому щільним інфільтратом, при проведенні стандартної ЛХЕ спостерігали в одного з 23 хворих (4,3 \%) групи порівняння.
\end{abstract}

Ключові слова: жовчнокам’яна хвороба; холецистит; холецистектомія; лапороскопія; мінілапаротомія; лапаротомія; конверсія; ускладнення. 